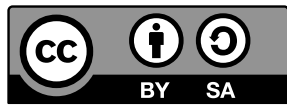

\title{
ITALIJANŠČINA KOT TUJ JEZIK NA PODROČJU GOSTINSKO-TURISTIČNE STROKE - PREUČITEV USTREZNOSTI BESEDIL IN NALOG V UČNIH GRADIVIH TER PREDLOGI
}

\section{UVOD: UVODNE MISLI O UČITELJU TUJEGA JEZIKA STROKE KOT SNOVALCU UČNIH GRADIV}

Poučevanje in učenje tujih jezikov stroke (odslej: TJS) danes pomeni strokovno jezikovno izobraževanje in vključuje učenje tujih jezikov bodisi za izvajanje določenega poklica, torej učenje tujega jezika za posebne strokovne namene (angl. Languages for Specific Professional Purposes), bodisi učenje tujih jezikov stroke za posebne študijske namene (angl. Languages for Specific Academic Purposes). Pri TJS gre po definiciji Hutchinsona in Watersa (1987) za pristop k poučevanju jezika, pri katerem vse odločitve v zvezi z vsebino in metodami temeljijo na razlogih za učenje. Pouk TJS je torej vedno načrtovan tako, da zadovoljuje specifične potrebe učencev, da se poslužuje metodologij in dejavnosti, ki so prisotne v strokah, s katerimi je povezan, in da se osredinja na tiste jezikovne spretnosti in prvine, diskurz in žanr, ki so ustrezni za izvajanje teh dejavnosti (cf. Dudley-Evans in St John, 1998).

Dudley-Evans in St John (1998) ugotavljata tudi, da ima učitelj TJS več vlog, ki se med seboj ne izključujejo. V vlogi učitelja ni vedno tisti, ki o stroki oziroma nosilni vsebini največ ve, vsekakor pa je tisti, ki delo pri pouku organizira in je strokovnjak za jezikovno področje, torej dejansko vsebino. V vlogi načrtovalca pouka in pripravljavca gradiv mora velikokrat najprej izdelati učne priprave za pouk, ki so v skladu s potrebami udeležencev oziroma učnim načrtom. Ravno tako mora pripraviti ustrezna gradiva, kar v praksi pomeni, da mora $v$ vrsti različnih virov najti ustrezna gradiva in jih prilagoditi ali celo napisati nova in jih nato sproti evalvirati. Učitelj je tudi raziskovalec, ki mora biti na tekočem z najnovejšimi spoznanji na področjih analize potreb, zvrsti in diskurza, evalvacije, priprave študijskih gradiv in metodologije poučevanja (Djurić, Godnič-Vičič in Jurković, 2008).

Tudi West (1998) ugotavlja, da poučevanje TJS temelji na avtentičnih gradivih in raziskovanju ter poudarja tiste jezikovne elemente, ki ustrezajo namenu učenja. Ključnega in temeljnega pomena za kakovostno poučevanje TJS so torej učna gradiva. Dudley-Evans in St Johns (1998) celo menita, da gre pri tujih jezikih stroke za področje, ki je utemeljeno predvsem na učnih gradivih in metodah poučevanja. Zaradi specifičnosti 
posameznih strok, kontekstov učenja in poučevanja ter posledično specifičnih potreb učencev pa je na nekaterih področjih premalo tržno razpoložljivih gradiv, ki bi bila dovolj ustrezna (ali jih sploh ni), zato se učitelji večinoma odločajo za to, da gradiva za svoje študente pripravijo sami ali jih znatno priredijo (Hutchinson in Waters, 1987).

Svetlin-Gvardjančič (2008) poudarja, da mora učitelj TJS, kot prenašalec znanja, ki je osredotočen na usmerjanje in nadzor učnega procesa, z izbiro oziroma pripravo ustreznih gradiv zagotoviti razmere za pouk, ki je usmerjen $\mathrm{k}$ ciljni skupini, in da s posredovanjem strateškega in proceduralnega znanja učence pripravlja na avtonomno učenje in na rabo jezika v poznejšem poklicu. Tudi Jarc in Zorko (2013) izpostavljata, da mora učitelj TJS raziskati, kakšne so učenčeve ciljne potrebe glede na zahteve okolja, kjer bo jezik uporabljal. Na podlagi teh potreb lahko pripravi program oziroma samostojno oblikuje ustrezno študijsko gradivo. Pečnik (2001) ugotavlja tudi, da bi bilo potrebno posvetiti večjo pozornost snovanju učbenikov, pri čemer bi bilo potrebno upoštevati mnenja vseh udeležencev v procesu poučevanja TJS, torej učiteljev, avtorjev in dijakov.

Učitelj TJS, ki je tudi avtor učnega gradiva, mora znati iz več zornih kotov pretehtati, kako študijska gradiva zasnovati, prilagoditi, prikrojiti, da bodo vsebovala ustrezno strokovno vsebino in terminologijo in torej zadovoljila specifične jezikovne potrebe določene ciljne skupine. Pomemben namen gradiva naj bi bil tudi, da na jasen način prikaže in razloži tudi uporabne slovnične strukture in ponudi ustrezne slovnične naloge, ki bodo vsebovale ali se navezovale na strokovno izrazje. Poleg nazornega podajanja snovi v splošnem, naj bi študentom s pomočjo nalog in dejavnosti "produktivnega" tipa pomagal uriti pri ustnem sporazumevanju, značilnem za situacije in priložnosti, v katerih se bodo (študentje) poklicno znašli.

Dejstvo torej je, da je učbenik, kot navaja Skela (1993) še vedno »najpomembnejše učno sredstvo tujejezikovnega poučevanja in učenja. Če učbeniki danes bolj kot kdajkoli prej določajo zgradbo in potek organiziranega oziroma institucionaliziranega tujejezikovnega pouka in učenja, je seveda pomembno vprašanje, po katerih oziroma kakšnih kriterijih bi jih morali ocenjevati, vrednotiti, proučevati, prirejati in tudi ustvarjati«. V okviru možnih področij analize učbenikov obstajata dve najširši področji obravnave, in sicer: vsebinsko področje, ki se nanaša na to, kaj je v gradivu (tj. jezikovna in nejezikovna vsebina) in učno področje, ki se ukvarja s tem, kako se vsebinsko področje obravnava oziroma posreduje (prim. Skela, 2008).

\section{VIDIKI IN VPRAŠANJA ZA ANALIZO OBSTOJEČIH STROKOVNIH UČNIH GRADIV ZA PODROČJE GOSTINSTVA IN TURIZMA}

V prispevku se bomo osredotočili tako na vsebinsko področje, torej na analizo jezikovne vsebine, kot na učno področje (na metodološko glotodidaktično vsebino): tipologijo nalog oziroma na strukturo dejavnosti za razvijanje učenčeve govorne zmožnosti v 
razpoložljivih strokovnih učbeniških gradivih, ki so nastali v slovenskem prostoru v preteklih sedmih letih (v pričujočem prispevku jih poimenujemo kot učbenik $\mathrm{A}^{1}$, učbenik $\mathrm{B}^{2}$ in učbenik $\mathrm{C}^{3}$. Pripravili so jih slovenski učitelji italijanščine kot TJS ter namenili študentom višješolskega strokovnega programa Gostinstvo in turizem, ki si izberejo predmet Italijanščina kot tretji tuji jezik in ki še nimajo ne splošnega ne strokovnega predznanja jezika. Višješolski študentje s pomočjo učnega gradiva razvijajo jezik na različnih področjih jezikovnih spretnosti: v italijanščini urijo bralno in slušno razumevanje, ter ustno in pisno sporazumevanje, vse ob temah strokovnega področja. Glede na predvidene vsebine učnega načrta naj bi študenti dosegli raven znanja A1 in obenem povečan obseg razumevanja ter tvorjenja strokovnih besedil s področja gostinstva in turizma.

V prispevku se bomo primarno spraševali, a) v kolikšni meri in s pomočjo kakšnih nalog in dejavnosti za urjenje lahko učenec razvija komunikacijsko spretnost govornega sporazumevanja, ki mu bo služilo pri opravljanju svojega poklica, in b) v kolikšni meri so primerne naloge za razvijanje te sporazumevalne veščine prisotne (odslej jih poimenujemo ,produktivne naloge', torej take ob katerih poteka urjenje uporabe TJS), predvsem pa kakšne so po vsebini: v kolikšni meri učenca usmerjajo in pripravljajo na samostojno komuniciranje v različnih, bolj ali manj zahtevnih, poklicnih situacijah ali okoliščinah.

$\mathrm{V}$ našem primeru gre za vlogo receptorja $\mathrm{v}$ nastanitvenih obratih, vlogo natakarja $\mathrm{v}$ baru ali v restavraciji in ostalih gostinskih obratih, vlogo zaposlenega na blagajni v raznih kulturnih in turističnih ustanovah (npr. muzejih, gradovih itd.). Pod drobnogled smo vzeli učne enote oziroma teme, ki se nam zdijo za bodoče zaposlene v turizmu in gostinstvu na ravni A1 najbolj pomembne, in sicer: primi contatti (slov. prvi stiki s strankami na recepciji, v baru ali v restavraciji, na blagajni, pri prodaji vstopnic itd.); al bar e al ristorante (slov. v baru in v restavraciji); alla reception (slov. na recepciji).

$\mathrm{V}$ članku se bomo nadalje osredotočili tudi na sama besedila in naloge za razvijanje bralnega razumevanje: raziskali bomo, v kolikšni meri so v učbenikih prisotna avtentična gradiva in avtentične naloge, ter koliko je vsebina besedil uporabna in koristna za študente gostinstva in turizma. Poleg tega v prispevku obravnavamo, v kolikšni meri je strokovna terminologija integrirana $v$ razlago, predstavitev in utrjevanje najpomembnejših slovničnih struktur ravni A1, ki so (lahko) osnova za (kasnejše) tvorjenje strokovne konverzacije. V naši analizi ugotavljamo torej danosti obstoječih učnih gradiv za gostinstvo in turizem ter predlagamo nekaj sprememb oziroma ustrezne dopolnitve, kjer zaznavamo vsebinske ali metodološke primanjkljaje.

1 Maričić, Maja (2009) Strokovna terminologija v italijanskem jeziku. Ljubljana: Zavod IRC. ISBN 978-961-682018-9, 182 strani, prosto dostopno na: http://www.impletum.zavod-irc.si/sl/gradiva/

2 Maričić, Maja (2010) Strokovna terminologija v tujem jeziku 3-italijanski jezik. Učbenik sicer v letu 2011 ni bil sprejet in potrjen preko projekta Impletum, čeprav je šlo za drugi, v velikem delu prenovljeni učbenik, vendar istim avtorjem zaradi prevelikega odziva niso omogočili objave v okviru projekta. Trenutno (oktober, 2017) je učbenik $\mathrm{v}$ postopku druge potrditve. V zadnjem letu je bil zaradi objektivnih razlogov v nekaterih učnih enotah prenovljen, vendar ne $\mathrm{v}$ tistih, ki so predmet naše analize.

3 Gomzi Praprotnik, Silvana (2011) Strokovna terminologija v italijanskem jeziku III. Ljubljana: Zavod IRC. ISBN 978-961-6857-75-8, 186 strani, prosto dostopno na: http://www.impletum.zavod-irc.si/s1/gradiva/ 


\subsection{Tipologija učbeniških gradiv}

V grobem lahko delimo učbenike na tradicionalne in komunikacijske učbenike (Grant, 1987). Tradicionalni učbeniki skušajo učence pripraviti do tega, da bi se učili jezika kot sistema. Bolj kot komunikacijske funkcije jezika poudarjajo pomen jezikovnih oblik, vzorcev, slovničnih struktur; temeljijo na pisnih nalogah, ki poudarjajo pomen jezikovne pravilnosti; dokaj ozko sledijo predvsem slovnično osredinjenem učnemu načrtu in tovrstnemu končnemu preverjanju pridobljenega znanja. Tisti, ki jih pri učenju uporabljajo, se solidno seznanijo s slovnico (jezikovnim sistemom), vendar se pogosto niso sposobni $\mathrm{v}$ jeziku tudi sporazumevati.

Komunikacijski učbeniki poudarjajo pomen komunikacijskih funkcij jezika - torej vsega tistega znanja, ki je potrebno, da ljudje jezik uporabljajo - in torej ne le jezikovnih oblik. Skušajo, kolikor je to mogoče, zadovoljiti potrebe in interese učečih se, poudarjajo sporazumevalne veščine, učenje pa temelji na aktivnostih. Bistveno večji poudarek je na poslušanju in govorjenju kot na pisanju in branju (Rižnar, 2008), bolj eksplicitno so razloženi cilji jezikovnega učenja in poučevanja, poudarjajo pomen uravnoteženosti med tekočnostjo in pravilnostjo izražanja v TJ ter se, ne nazadnje, zavedajo pomena besedil, ki morajo odražati avtentičen jezik iz vsakdanjega življenja.

Analizirana tri študijska gradiva (A, B in C) so učbeniki z elementi delovnega zvezka, namenjeni so enaki ciljni skupini, ter obravnavajo podobne tematike, ki se večinoma pojavljajo v vseh treh analiziranih učbenikih. Dva od treh analiziranih učbenikov (učbenik A in B) sta zasnovana $\mathrm{z}$ upoštevanjem komunikacijskega pristopa in sta namenjena predvsem učenju sporazumevalnih vzorcev in strokovne terminologije, slovnica služi kot podpora na poti do teh ciljev. Vaje vključujejo naloge za bralno razumevanje, naloge za govorno in pisno sporazumevanje (npr. igra vlog), pa tudi predstavitev relevantnih slovničnih struktur s shematičnimi prikazi in vajami.

Eden izmed analiziranih učbenikov (učbenik C) je nekoliko bolj tradicionalen (po Grantu 1987), saj daje slovnici precej večji pomen kot ostala dva učbenika: slovnica ima v večini učnih enot prednost pred učenjem komunikacijskih vzorcev in strokovnega besedišča, poleg tega vsebuje več vaj za razvijanje bralnega razumevanja in v nekoliko manjšem obsegu naloge za razvijanje govornega in pisnega sporazumevanja (Maričič, 2011; Mertelj, 2011a; Stanič, 2012).

\subsection{Spoznavanje in urjenje rabe ustaljenih izrazov za strokovno sporazumevanje}

Prva enota, ki smo jo analizirali, je uvodna enota, ki je v vseh treh učbenikih namenjena tematiki prvih stikov (učbenik A: Presentarsi, učbenik B: Primi contatti, učbenik C: Primi contatti). Učenci doživijo prvi stik z jezikom v govorni in bralni obliki, zato je pomembno, da gradiva ustaljene izraze za lažje sporazumevanje (pozdravi, vljudnostni 
izrazi, uporabne predstavitvene fraze, želje), vključujejo od prvih enot dalje in na ta način spodbudijo učence k aktivni rabi jezika že od začetka učnega procesa, poskrbijo torej tudi za njihovo utrjevanje.

Ustaljeni izrazi za začetno interakcijo so v vseh treh učbenikih predstavljeni ob situacijskih dialogih in s pomočjo nalog za razvijanje bralnega razumevanja. V učbenikih A in C je situacija nedoločljiva (oz. splošna), v učbeniku B se situacijski dialog dogaja na recepciji hotela. V nobenem od treh učbenikov pa ni na voljo nobene naloge, kjer bi lahko učenci vadili formalne in neformalne pozdrave ob snidenju in odhodu, vljudnostne fraze pri seznanjanju oziroma predstavljanju, vljudnostne nagovore ob sprejemanju gostov, obiskovalcev itd.

Ker bi moralo biti poučevanje in učenje $\mathrm{v}$ gostinsko turistični stroki usmerjeno $\mathrm{k}$ uporabi znanja in k realnim situacijam, bi bilo smiselno, da ustaljene izraze in osnovne značilne govorne fraze za navezovanje stikov učencem predstavimo preko dialoga, ki ga umestimo $\mathrm{v}$ ustrezen strokovni kontekst, na primer kot pogovor na recepciji hotela (ob prihodu v hotel in ob odhodu iz hotela), pogovor v baru ali restavraciji, pogovor v informacijskem centru ali na blagajni pred vhodom v kulturno turistične ustanove.

Učbenik $\mathrm{C}$ ne vsebuje nobene ,produktivne“ naloge, ob kateri bi učenci uporabili sporazumevalne vzorce, ki so jih spoznali do te mere, da jih razumejo. Učbenik A pa vsebuje dve taki nalogi, vendar sta umeščeni v splošne, vsakdanje situacije, ne pa v poklicno specifične (Primer naloge iz učbenika A: Tvorite podobne dialoge, kot so prikazani na začetku enote. Zdaj zaigrajte razgovor: ste na zabavi, kjer ne poznate veliko ljudi. Predstavite se in spoznavajte ljudi okoli sebe.)

Samo v učbeniku B so prisotne produktivne naloge, in sicer gre za igre vlog, kjer lahko učenci urijo konverzacijo ob sprejemu gosta v hotel ali kateri drugi nastanitveni objekt (Primer naloge iz učbenika B: Formate dei dialoghi (lavorando in coppia). Chiedete il nome, la provenienza e l'età.: sig. Paolo Frecci (Milano, 35), sig.ra Anna Mauro (Napoli, 42), Giancarlo (Padova, 18), Franco (Livorno, 21) itd.

Predlagamo, da učencem s pomočjo vzorčnih dialogov v prej navedenih turistično gostinskih situacijah predstavimo možnosti vzpostavitve prve interakcije z uporabo ustaljenih izrazov, npr. Leggete i tre dialoghi seguenti e osservate le espressioni dell'ospite e del receptionist, le espressioni dell'ospite e del cameriere, le espressioni dell'ospite e dell'addetto alla biglietteria. Trovate nel dialogo precedente le espressioni seguenti.

$\mathrm{Z}$ ostalimi frazami, pozdravi in željami lahko učence seznanimo tako, da povežejo izraz v italijanščini z izrazom v slovenščini, nalogam za razumevanje besedil naj sledijo „produktivne“ naloge, v katerih učenci uporabljajo jezik, in sicer igre vlog, ko učenci v parih ali v skupini med seboj ustno tvorijo dialoge v različnih vlogah (prej si pripravijo pisne oporne točke, prevajajo dialoge iz slovenščine v italijanščino, nato pa s pomočjo fotografije, ki jim je dana, simulirajo pogovor v različnih situacijah na recepciji, v baru, v restavraciji, na blagajni vstopnic kulturnih znamenitosti), npr. Osservate le foto e cercate di immaginare la situazione. Simulate (oralmente) il dialogo alla reception, in 
biglietteria, al bar/al ristorante. Per agevolare la vostra produzione orale, potete tradurre le frasi dei dialoghi dallo sloveno in italiano.

Učenci tako 'odigrajo' vlogo receptorja in gosta, natakarja in gosta, prodajalca vstopnic in gosta, na ta način se lahko (na)učijo splošne in specifične ustaljene izraze, ki so zelo uporabni tako v vsakdanjih situacijah, predvsem pa na področju njihove stroke. Ko se učenci naučijo pozdravov in najosnovnejših ostalih izrazov, jih seznanimo še z najpogostejšimi vprašalnicami oziroma vprašanji, ki naj bi jih učenci znali uporabljati na delovnem mestu, predvsem ob sprejemu gostov na recepciji (vprašanja po imenu, starosti, izvoru, dokumentih, telefonski številki, naslovu, datumu rojstva, skratka o podatkih, ki jih zaposleni na recepciji potrebuje za vpis v evidenco prisotnosti v nastanitvenem obratu). Take naloge naj bi se glasile, npr. Usando i dati seguenti e con l'aiuto dei dialoghi precedenti, fate dei dialoghi in coppia scambiando i ruoli del receptionist/ del camerierel della guida turistica/ del massaggiatore e del cliente. Simulate quindi i dialoghi alla reception, in biglietteria, al bar / al ristorante, nel centro benessere.

\subsection{Osredotočenost na učenca in njegove konkretne poklicne potrebe}

Strokovno ustrezen učbenik TJS naj bi pokrival teme, ki so relevantne za študente, ki naj bi poleg osnovnega splošnega znanja pridobili oziroma nadgradili osnovno znanje na področju jezika stroke. Prva pomembna značilnost oziroma prednost strokovno ustreznega učbenika ali učnega materiala je osredinjenost na učenca in njegove konkretne jezikovne potrebe, ki se povezujejo z opravljanjem poklica. Snov oziroma učne vsebine naj bi bile izbrane glede na dejansko sporazumevalno potrebo v praksi (tj. na delovnem mestu), situacije in položaji morajo biti torej interdisciplinarni, realni, življenjski, tako da je takoj očitna uporaba jezikovne snovi v resničnem poklicnem življenju.

Vsi trije preučeni učbeniki vsebujejo lekcije z gostinsko tematiko (npr. »Bere e mangiare qualcosa», »Al bar«, »Prendere qualcosa al bar», »Al ristorante«). V vseh treh učbenikih so prisotne tudi „produktivne“ naloge, v največji meri igre vlog, kjer učenci tvorijo npr. dialoge v baru s pomočjo seznama besediščnih iztočnic (npr. na fotografijah ali na seznamu ali na kopiji cenika ipd.). Gre za dialoge med samimi gosti ter med gostom in natakarjem: prve naj bi turistični delavec predvsem dobro razumel, v drugem primeru pa tudi aktivno govorno in vsebinsko sodeloval.

Toda večina situacijskih dialogov (predvsem v učbeniku C) je v prvem delu učne enote sestavljenih tako, da učenci sporazumevalne veščine in vzorce vadijo predvsem v vlogi gosta. Glede na to, da gre za študente gostinstva, turizma in velnesa (torej za strokovno terminologijo $\mathrm{v}$ tujem jeziku stroke, ki jo bodo učenci potrebovali pri svojem delu), se dialogi in predvsem naloge premalo osredotočajo na vlogo turističnega delavca, ki je za študente in njihov (sedanji ali bodoči) poklic bistvenega pomena. 
$\mathrm{V}$ učbenikih A in B je na koncu lekcije, ki obravnava dejavnosti in storitve v baru 'produktivna' naloga, ob kateri naj bi učenci ponovili snov, ki naj bi jo usvojili ali se je naučili v predhodnih delih učne enote. Učenci morajo izraze, stavke in vprašanja prevajati iz slovenščine $\mathrm{v}$ italijanščino in obratno, toda tudi v primeru učbenikov $\mathrm{A}$ in $\mathrm{B}$ gre večinoma za vidik gosta (Primeri naloge iz učbenikov A in B: Traducete le frasi: Dire di volere mangiare, Chiedere com'è il cibo, Ordinare da bere, Ordinare da mangiare, Chiedere il conto, Chiedere quanto costa qualcosa). Med številnimi tovrstnimi utrjevanji govornih dejanj gosta sta podana samo dva primera vprašanj, ki jih zastavi npr. natakar (Primeri iz učbenikov A in B: Dober dan, želite?, Dober dan, prosim?). Seveda je pomembno, da se učenec TJS tudi sam nauči naročiti pijačo in hrano, da zna vprašati za račun, ipd., saj s tem bolje razume zahteve, želje, preference gosta v baru, relevantno in poklicno nujno pa je, da se nanje pravilno jezikovno odzove, ne le, da se ustrezno obnaša.

Torej že v prvih učnih enotah učenec TJS na področju gostinstva in turizma ni ustrezno voden, saj se mora (po učnem načrtu in katalogu znanj strokovne terminologije v tujem jeziku) naučiti goste ob prihodu ustrezno pozdraviti, jih sprejeti, od gostov dobiti naročilo, torej njihova naročila razumeti, jih postreči, jim med postrežbo izkazati naklonjenost, ustrežljivost, na prošnje gostov primerno odgovoriti, se odzvati, pripraviti račun in jim ga prinesti, z ustreznimi izrazi od njih zahtevati plačilo, se zahvaliti in jih ob odhodu pozdraviti. Učenec v vlogi natakarja mora znati tudi našteti pijačo in hrano, ki jo ima lokal v ponudbi, česa nima v ponudbi, česa ni več na razpolago, v tujem jeziku mora znati svetovati, če pride do nevšečnosti, se mora znati tudi ustrezno opravičiti. Vsa ta poklicna dejanja terjajo uporabo ustreznega jezika, pa naj je ta še tako rudimentaren.

Tudi v lekcijah, ki zadevajo storitve in ponudbe v restavraciji, so 'produktivne' oz. komunikacijske naloge $\mathrm{v}$ vseh treh učbenikih zastavljene tako, da učenci večinoma vadijo uporabne stavke, fraze, prošnje, vprašanja, ki jih v restavraciji postavljajo gostje (Primeri naloge iz učbenikov A in B, reklamacije: Zrezek je pretrd., Juha je mrzla., Solata ni sveža., Meso je premalo kuhano., Žlica je umazana. Prt ni čist. ipd.), kar je sporno iz vidika, da gre za učbenik TJS. V učbenikih A in B vsako enoto zaključuje 'produktivna naloga', in sicer učni prevodi povedi iz slovenščine v italijanščino, ki učenca neposredno usmerjajo k ponovitvi pomembnih govornih dejanj za posamične sporazumevalne funkcije, toda tudi na koncu učnih enot so dani primeri stavkov, fraz, vprašanj in prošenj, ki jih v restavraciji uporabljajo in izrekajo gostje, ne pa tudi turistični delavci oz. je teh bistveno manj: učenec ima v učbenikih A in B na razpolago le nekaj primerov, kjer lahko v vlogi natakarja v restavraciji sprejme naročilo in poda gostom priporočila, in sicer; Kaj želite za predjed?, Priporočam vam meso na ražnju., Danes imamo postrv na žaru.

Naloge učnih prevodov so sicer izredno dobra vaja, saj so v učnih prevodih vključeni vsi pomembni učni cilji, ki naj bi jih učenci po vsaki predelani enoti znali uporabljati za komunikacijo v tujem jeziku stroke, toda pomanjkljiva je njihova vsebina, oz. neproporcionalno visoki deleži govornih dejanj gostov. Ustreznejše bi bilo, da imajo učenci na razpolago (več) možnosti prevajanja in memoriranja konkretnih in pogostih 
povedi in fraz, ki so del poklicnega (tujega) jezika turističnega delavca pri delu s strankami. Naši predlogi se glasijo: Traduci le frasi e le espressioni che usa il cameriere dallo sloveno in italiano. Come accogliere i clienti al bar/al ristorante. Come prendere un'ordinazione al barlal ristorante. Come spiegare, elencare, dare consigli, reagire e rispondere alle domande degli ospiti. Come fare e portare il conto e salutare gli ospiti al bar/al ristorante.

Ker gre za študente, ki bodo stregli hrano in pijačo v restavracijah, gostilnah, hotelih ipd., bi bilo torej koristno, da imajo v učbenikih podanih veliko več priložnosti za urjenje razumevanja in konverzacije z italijanskimi gosti, saj bodo morali obvladati cel niz govornih dejanj v TJS: goste ob prihodu v restavracijo (hotel) ustrezno (tudi jezikovno) sprejeti (jih pozdraviti, poskrbeti za njihovo garderobo), jih z ustreznimi frazami posesti ob želeno, rezervirano ali prosto mizo, jim s pravilnimi izrazi ponuditi jedilnik in vinsko karto, sprejeti in njihova naročila razumeti, jim svetovati določene jedi (hišne specialitete, hišne sladice, hišna vina, dnevne menije, tipične lokalne jedi), našteti in razložiti, za katere in kakšne jedi gre, med obrokom na prošnje gostov z ustreznimi stavki odreagirati, na koncu povprašati, če so jim bile jedi všeč, prinesti račun in jim ga z ustreznimi besedami podati, se na pritožbe gostov ustrezno odzvati, se opravičiti, jim ob odhodu podati garderobo, jih pozdraviti in izraziti željo po ponovnem snidenju.

Iz besedil, nalog in dejavnosti, ki jih ponujajo preučevani trije učbeniki, učenec ne more črpati v zadostni meri priložnosti, da vadi oz. se (na)uči komuniciranja, ki ga zahteva gostinsko turistična stroka. Besedila, zlasti pa aktivnosti in vaje za uporabo jezika, morajo biti oblikovani s stališča predstavnika stroke, torej turističnega delavca (receptorja, natakarja, maserja, turističnega ponudnika itd.), ne pa zgolj iz vidika uporabnika storitev ali blaga (turista, stranke, gosta, obiskovalca itd.). Turistični delavci morajo razviti primerno raven razumevanja jezika svojih strank, tj. uporabnikov njihovih storitev, sicer sporazumevanje ne more potekati, toda enako ključno je urjenje uporabe TJS z značilnimi govornimi dejanji turističnih delavcev.

\subsection{Avtentičnost gradiva in nalog}

Učno gradivo mora temeljiti na poučevanju tujega strokovnega jezika na receptivni in na produktivni ravni in na usvajanju strokovnega izrazja ob obravnavi avtentičnih besedil in nalog (Jarc in Zorko, 2013). V vseh treh analiziranih učnih gradivih je na voljo vsaj ena lekcija, posvečena hotelu oziroma sprejemu gostov na recepciji. Vsi trije učbeniki vsebujejo primere ,receptivnih“ nalog, kjer učenci v danih dialogih ali besedilih iz italijanščine v slovenščino prevajajo izraze in fraze, $v$ italijanščini odgovarjajo na vprašanja, ki se nanašajo na dialog ali z navedenemi izrazi izpolnjujejo manjkajoče besede v sorodnem besedilu (Primeri nalog iz učbenikov A, B in C: Trovate le espressioni italiane corrispondenti alle slovene nei dialoghi di sopra. / Leggete la conferma della prenotazione e la composizione 
della lettera. / Leggete il dialogo e trovate le risposte alle seguenti domande. / Completate le conversazioni telefoniche tra il receptionist $(R)$ e il cliente $(C)$. itd.)

Prav tako vsi trije učbeniki vsebujejo primerne 'produktivne' naloge (primeri nalog iz učbenikov A, B in C): Scrivete una prenotazione telefonica. Lo studente A è ospite, lo studente $B$ è ricezionista (2 adulti, 1 bambino, camera matrimoniale, lettino aggiunto, due settimane, $1 / 7-15 / 7$,

ali: Ora scrivete voi una lettera di prenotazione e una di conferma. ali: Scegliete 4 alberghi sloveni di diverse categorie (anche pensioni familiari, agriturismi ecc.) che conoscete e preparate una descrizione scritta aiutandovi con i testi a pagina precedente e il lessico alla pagina seguente.

ali: Scegliete un albergo sloveno che conoscete e preparate una descrizione orale efficace di circa 10 minuti, per una fiera turistica.)

Vendar kljub prisotnosti ustreznih besedil in nalog menimo, da je v vseh treh študijskih gradivih premalo avtentičnega gradiva, kot npr. učne dejavnosti ob originalnih turističnih brošurah, prospektih, ponudbah počitniški objektov in ostalih turističnih storitev na spletnih straneh in drugod. Preko izvirnih besedil lahko namreč učenci spoznajo ne le terminologijo, ki jo bodo uporabljali pri promociji, oglaševanju, ponudbi nastanitvenega objekta, v katerem so ali bodo zaposleni, pač pa celoten strokovni in jezikovni kontekst, zato je integriranje avtentičnega turističnega materiala v učbenike za turistično gostinsko stroko bistvenega pomena.

Večina avtorjev pod pojmom avtentično gradivo razume neobdelana besedila, katerih avtorji so rojstni govorci in so namenjena drugim rojstnim govorcem v komunikacijske namene: gre torej za gradiva, ustvarjena v realnih življenjskih situacijah in ne za potrebe učenja jezika (Cuq, 2003; Cuq in Gruca, 2002; Grellet, 1981; v Lah, 2010). Za naše predloge smo za bralno razumevanje in spoznavanje strokovnega izrazja uporabili primer popolnoma avtentičnega gradiva (iz italijanskega turističnega tržišča) in nekaj avtentičnih prevedenih besedil (gre za pristna slovenska promocijska, predstavitvena besedila, ki so prevedena v italijanski jezik in namenjena italijanskim gostom). Med naše predloge smo vključili izvirna besedila o hostlu (Hostel Barovc, Kranjska Gora), o dveh hotelih (City Hotel, Ljubljana; Hotel Mirage, Rim) in o počitniški hiši (Hiša Neža, Kranjska Gora), ki so prosto dostopna na spletu. Gre za promocijske opise nastanitvenih struktur, ponudbe brezplačnih in plačljivih storitev, opis krajev, kjer se objekti nahajajo, opis aktivnosti, ki jih gostje lahko opravljajo v kraju in njegovi okolici.

$\mathrm{S}$ pomočjo originalnih besedil smo sestavili naloge, kjer učenci vadijo bralno razumevanje, v besedilih iščejo ustrezne slovenske izraze, ki se ujemajo z italijanskimi, v italijanščini odgovarjajo na vprašanja, ki se nanašajo na dane tekste in se na ta način seznanjajo, učijo in nadgrajujejo uporabno strokovno besedišče. Naši predlogi se glasijo, npr. Leggete i testi originali dell'ostello Hostel Barovc, Kranjska Gora, dell'albergo City Hotel Ljubljana, dell'Hotel Mirage, Roma, della casa appartamenti Hiša Neža, Kranjska Gora e trovate le espressioni richieste e rispondete alle domande. 
Kot že rečeno, je v vseh treh učbenikih kar nekaj ustreznih 'produktivnih' nalog (prevajanje iz slovenščine v italijanščino, odgovarjanje na vprašanja v italijanščini, igre vlog). Vseeno se nam zdijo ,produktivne“" naloge premalo avtentične. Pri vključevanju avtentičnih nalog in gradiva v učno situacijo moramo najprej premisliti, s kakšnim namenom in katere avtentične oblike nalog vključujemo. Newby (2000) opredeli avtentičnost naloge kot možnost avtentičnega obnašanja (ang. authenticity of behaviour), kar se nanaša na učenčevo uporabo TJS v dejavnostih in ob nalogah, ki so jim izpostavljeni. Po Skupnem evropskem jezikovnem okvirju $(2001,2011)$ gre za naloge, ki so vsekakor bližje »tujejezikovnim opravilom« in so oddaljene od slovničnih vaj, saj razvijajo komunikacijo ob nalogi, ki simulira značilno govorno sporazumevanje kot dela poklica, najpogosteje kot igra vlog in/ali dialogiranje s sporočilnimi vrzelmi. Ob takšnih nalogah učenci v razredu vadijo sporazumevanje v vsakdanjem življenju oz. TJS uporabljajo, da »rešijo« neko svojo potrebo po informaciji ali storitvi. Jezik v avtentičnih nalogah je za učence smiseln, cilji dejavnosti pa jasno zastavljeni (Dagarin-Fojkar, 2008), naš predlog se glasi, npr. Preglej naslednje ponudbe na internetu in rezerviraj nastanitev $v$ Rimu, ki bi ustrezala potrebam tebe in tvojih dveh prijatelev, ko greste tja za 4 dni na enogastronomski sejem.

Vedno bolj oziroma prevladujoče ne-avtentična postaja v vseh treh učbenikih tudi igra vlog, ki predpostavlja rezervacijo sobe prek telefonskega klica. Danes tujci oziroma turisti večinoma izvedejo rezervacijo preko spletnih turističnih portalov za rezervacije (npr. Booking.com, I feel Slovenia, Visit Ljubljana, Trivago.si, Travel.Over.Net, Lonely Planet, Trip Advisor, Hostelworld, Hostelling International, itd.), preko obrazca na spletni strani samega nastanitvenega objekta, preko e-maila in le zelo redko preko telefona.

Dogaja se sicer tudi, da se turisti na recepcijah slovenskih hotelov pojavijo brez predhodne rezervacije, zato je zelo pomembno, da znajo učenci, ob prihodu takih gostov preveriti in ponuditi razpoložljive sobe glede na njihove potrebe in zahteve, da znajo podati gostom še vse ostale potrebne informacije (npr. cena nočitve, turistične takse), da jih znajo seznaniti s ponudbami, s popusti ali brezplačnimi nastanitvami, npr. za otroke do določene starosti. V kolikor ni na voljo ustreznih sob, se morajo znati bodoči receptorji opravičiti in turiste $\mathrm{s}$ tem seznaniti. Naši predlogi zato vsebujejo 'produktivne' naloge igre vlog, kjer gre za simuliranje raznih tovrstnih situacij, npr. Dei turisti italiani sono alla ricerca di un alloggio e si recano nella vostra struttura per sapere quali tipologie di camere sono disponibili. Verificate la disponibilità delle camere tenendo conto del numero di persone e delle loro esigenze fornendo loro tutte le informazioni relative al prezzo della camera, al costo della tassa di soggiorno, alle eventuali riduzioni e offerte di soggiorno gratuite per i bambini. Fate dei dialoghi simulando entrambe le seguenti situazioni: 1) le camere sono disponibili; 2) tutte le camere sono occupate. Esempio 1: Dei turisti italiani stanno cercando un alloggio per quattro notti in un albergo a Ljubljana. Sono in due. Due adulti. Esempio 2: Dei turisti italiani stanno cercando un alloggio per una settimana in un albergo a Kranjska Gora. Sono in sei. Due famiglie, ciascuna con un 
bambino di 4 e 6 anni. Bambini fino ai 4 anni soggiornano gratis. Esempio 3: Dei turisti italiani stanno cercando un alloggio per tre notti in un ostello a Ljubljana. Sono in sette. Sette giovani ragazzi.

Učenec mora znati ob tem tudi ustrezno opisati sobe in kopalnice, ki jih gostom ponuja (kakšne so sobe, kam so obrnjene, kaj soba ponuja, kakšne so kopalnice, kaj ponujajo itd.). Šele na podlagi teh podatkov se lahko turisti odločijo, ali bodo nastanitev sprejeli ali ne. Tudi na tem mestu naši predlogi vključujejo naloge razumevanja vzorčnih dialogov, ki jim sledijo produktivne naloge, v obliki iger vlog, dialogov med zaposlenimi na recepciji in italijanskimi turisti, npr. Dei turisti italiani entrano nella vostra stuttura e chiedono informazioni sulle caratteristiche delle camere e dei bagni. Simulate dialoghi descrivendo le camere e i bagni della vostra struttura alberghiera. Alla reception in un albergo. Alla reception in una pensione. Alla reception in un ostello. Alla reception in un albergo familiare. Esempio1: Gli ospiti del vostro albergo vogliono una camera spaziosa e tranquilla con balcone, che da sul parco. Vogliono la TV e la radio in camera. Vogliono sapere com 'è il bagno e di che cosa dispone. Esempio 2: Gli ospiti del vostro albergo vogliono una camera moderna e silenziosa, che da sull'interno. Vogliono il servizio in camera e un tavolo in camera. Vogliono avere una vasca da bagno e un asciugacapelli.

Kot že navedeno, se najbolj pogosto v turističnih nastanitvenih objektih na recepciji pojavijo gostje, ki so sobo že vnaprej rezervirali. Tudi v takih primerih morajo znati bodoči receptorji gosta ob prihodu primerno (ne le vsebinsko, tudi jezikovno) sprejeti (pozdraviti in izraziti dobrodošlico), si priskrbeti vse potrebne podatke (vprašati po imenu, na katero imajo rezervacijo, po osebnem dokumentu, po podatkih kreditne kartice, ki jih potrebujejo kot garancijo glede plačila rezervacije) in mu ponuditi informacije in usluge (številka sobe in nadstropja, podati ključe, informacije o restavraciji hotela glede obrokov, glede njihove samopostrežnosti, brezplačnosti, doplačevanja).

Njegove (tudi jezikovne) naloge presegajo prostor recepcije, saj podaja tudi informacije glede znamenitosti, dogodkov in praktičnih zadev v mestu in okolici npr. zemljevid mesta, katalogi, brošure itd. Nenazadnje morajo bodoči receptorji znati gostu zaželeti prijetno bivanje, predvsem zadnji dan bivanja v hotelu pa se mu primerno (jezikovno) zahvaliti, zaželeti srečno pot in povabiti k ponovnem bivanju pri njih. Vse navedene sporazumevalne funkcije naj bi vsebovala besedila za jezikovni vnos v učnih enotah, sledile naj bi mu naloge, ki naj bi zagotovile učencem jezikovni ,prevzem‘ (angl. intake), predvsem naj bi to bile različice iger vlog, npr. Preparate degli appunti scritti e fate dei dialoghi orali simulando varie situazioni: tra il receptionist e gli ospiti di un albergo, una pensione, un ostello, un albergo familiare. Esempio 1: un signore che soggiorna in albergo per lavoro, prenotazione di una camera singola per 2 notti a nome Simone Valle, la camera 14, al secondo piano, le sue richieste, domande: la connessione internet in tutta la struttura, l'orario della colazione a buffet., in ostale naloge učnega prevajanja, kjer učenci utrjujejo ustaljene fraze tako, da jih prevajajo iz slovenščine v italijanščino, npr. Traducete le espressioni del receptionist dallo sloveno in italiano: Come accogliere 
l'ospite/il cliente al suo arrivo alla reception di una struttura alberghiera: Come rispondere agli ospiti alle loro richieste durante la permanenza in una struttura ricettiva: Come salutare gli ospiti/i clienti alla partenza dalla reception:/ Scegli l'espressione adeguata e traduci le frasi dallo sloveno in italiano.

Analiza je pokazala, da je v učbenikih $\mathrm{A}$ in $\mathrm{B}$ preveč poudarka na vlogi, ki jo imajo gostje počitniških objektov, namesto da bi bile vsaj v enaki meri na voljo naloge za »receptorjeva « govorna dejanja, v učbeniku $\mathrm{C}$ pa je takih produktivnih nalog (ki poudarjajo vlogo receptorja: spraševanje gostov, reakcije na njihova vprašanja, prošnje in zahteve) bistveno več.

\subsection{Reklamacije in pritožbe}

Zadnji sklop naše preučitve učbenikov je tema, ki jo obravnavajo vsi trije učbeniki: pritožbe $\mathrm{v}$ nastanitvenih obratih. Učbenika A in B na to temo nudita sicer tri naloge receptivnega tipa (razumevanje jezikovnega vnosa) in eno 'produktivno' nalogo, a tudi v tem sklopu prevladuje vloga gostov, ki se pritožujejo (Primeri iz učbenikov A in B: Traducete le frasi dallo sloveno in italiano: V sobi je pokvarjena televizija., Luč se ne prižge., Jogi je pretrd., Okno se ne odpre.), premalo je poudarka na vlogi receptorja, ki pritožbe sprejme in se nanje odziva (razen v dveh primerih učbenikov $\mathrm{A}$ in $\mathrm{B}$, npr. Certo. Mi dica.) V učbeniku $\mathrm{C}$ je glede tega sklopa celo samo naloga bralnega razumevanja, brez vsakršne igre vlog ali učnih prevodov.

V realnih situacijah se dejansko mnogokrat zgodi, da gostom kaj ne ustreza, ali pa da gre za okvaro (aparata, ogrevanja itd.) ali nevšečnost, ki se dejansko pripeti med bivanjem v hotelu - vse to lahko privede do reklamacij ali pritožb na recepciji. Ker gre za ugled nastanitvenega objekta in obenem za zadovoljstvo strank hotela, je v interesu vseh vpletenih izjemno pomembno, kako odreagira receptor.

Učenec se mora torej naučiti, da se ustrezno, prijazno, profesionalno na pritožbe gostov odzove, tako vsebinsko (resnost, hitro urgiranje, zagotovila gostu) kot jezikovno, torej mora znati ustrezna jezikovna sredstva. Vse to se tudi $\mathrm{v}$ tem primeru učenec nauči preko pripravljanja in izvajanja iger vlog, od pritožbe preko telefona do osebnih pritožb na recepciji. Nalogam razumevanja "pritožbenih" govornih dejanj gostov morajo slediti 'produktivne' naloge, ki zahtevajo od učenca (kot bodočega zaposlenega na recepciji) predvsem izvajanje ustreznih ustnih odgovorov, ki jih mora ob pritožbi (znati) podati. Naši predlogi so, npr. Rispondi e reagisci adeguatamente ai reclami degli ospiti nella vostra struttura ricettiva. Esempio: Ospite: Scusi, signore, abbiamo un problema. L'aria condizionata nella nostra camera non si accende. Receptionist: 


\subsection{Umeščenost, razlaga in urjenje slovničnih struktur}

V vseh treh analiziranih učnih gradivih je del vsake ali večine lekcij namenjen predstavitvi in utrjevanju slovničnih struktur, ki so en od sestavnih delov sporazumevanja pri obravnavanih tematskih sklopih. V enem izmed treh učbenikov (učbenik C) imamo vtis, da je njegov glavni namen v precejšnji meri zgrešen, saj gre predvsem za učenje slovnice: $\mathrm{v}$ skoraj vseh lekcijah avtor hitro preide na predstavitev in vaje za urjenje slovničnih oblik, razvijanje sporazumevanja $v$ tujem jeziku stroke pa se zdi temu cilju podrejeno. $\mathrm{V}$ ostalih dveh učbenikih (učbenika A in B), ki sta v večji meri zasnovana v skladu s komunikacijskim pristopom, pa učenje in poučevanje ne temelji na slovnici, je pa ta kljub temu stalno in v ustrezni meri eksplicitno in sistematično obravnavana: ob shemah je predstavljena in razložena, precej je tudi nalog za urjenje in utrjevanje. Slovnični elementi so v omenjenih dveh učbenikih predstavljeni glede na kontekst, v katerem se nahajajo v učni enoti.

Slovnica je $\mathrm{v}$ analiziranih študijskih gradivih $\mathrm{z}$ obravnavano tematiko sicer resda povezana, a zelo pogosto je ta povezanost zelo ohlapna oz. ni povezave z gostinsko in turistično stroko. Ker vemo, da morajo ustrezna strokovna učna gradiva upoštevati načela komunikacijskega pristopa, slovnica tudi pri poučevanju/učenju tujega jezika stroke ne sme biti vodilo, pač pa naj bi bila podrejena strokovnim besedilom in obravnavanju strokovne terminologije: učne vsebine naj samo spremlja in dopolnjuje in jih ne določa. Prav s tem konceptom naj igra svojo (pomembno) vlogo pri poučevanju in učenju tujega jezika stroke, pri čemer naj študenti preko razlage in urjenja slovnice obenem utrjujejo tudi strokovno terminologijo, saj tako sproti utrjujejo in nadgrajujejo veliko besedišča s področja turizma, gostinstva in velnesa.

Pomembno je torej, da se jezikovne strukture sicer poučuje eksplicitno, z razlago slovničnih pravil in z utrjevanjem nove strukture. Na ta način učbeniki učence navajajo na abstraktnejše učenje jezika in na zahtevnejše miselne operacije (Dagarin-Fojkar, 2008). Urjenje pa naj bi potekalo ob vajah, ki se vsebinsko navezujejo na strokovno besedišče. Slovnične naloge, ki vsebujejo izrazje stroke, s katerimi utrjujemo določeno jezikovno strukturo in hkrati implicitno tudi strokovno besedišče, spodbujajo pravilno rabo jezika, prispevajo pa tudi k tekočnosti glede strokovnega jezika, saj se utrjuje terminologija. Tako s strokovno in obenem slovnično primernimi nalogami učence posredno dodatno navajamo na sporazumevalne vzorce, ki jih bodo uporabljali v svojem poklicu.

Večina slovničnih nalog v vseh treh preučenih učbenikih temelji predvsem na splošni pisni rabi jezika in primere črpa iz tržno dostopnih učbeniških gradiv splošnega jezika, mi pa predlagamo, da bi bile predstavitev, razlaga in urjenje najpogostejših slovničnih struktur za gostinsko-turistične poklice čim bolj usklajene s strokovnim področjem, da bi torej čim bolj upoštevale poklicne potrebe učencev. Slovnične naloge naj v ospredje postavljajo slovnico strokovnega govorjenja, kar temelji na predpostavki, da bo večina učenčeve vsakodnevne poklicne komunikacije potekala s pomočjo govora. Tako npr. naj bi pri razlagi abecede vključili izraze, ki so v turizmu in gostinstvu najbolj pogosti in ki 
jih bodo učenci v praksi dejansko lahko uporabljali, v vseh treh učbenikih pa so navedena imena italijanskih mest, torej namesto $» A$ come Ancona, B come Bologna, C come Como, « itd. predlagamo »A come ALLOGGIO, B come BAGAGLIO, C come CONTO, D come DOCUMENTO«itd.

Tudi spoznavanje in utrjevanje členov, spola in števila pridevnikov in samostalnikov poteka ob nalogah, ki vsebujejo splošni jezik, npr. 1) namesto ragazza è bionda, predlagamo npr. prenotazione di una camera si può fare per e-mail., 2) namesto Mio padre è molto alt_, predlagamo: Le camere sono singol_.

Podobno naj bi postopali pri utrjevanju spregatve glagolov biti, imeti, imenovati se, npr. namesto »Marco un amico." predlagamo »Scusi, signore, la carta d'identità? «.

Že pri samem uvajanju pravilnih, nepravilnih in povratnih glagolov v sedanjiku strokovne vsebine $\mathrm{v}$ preučenih treh učbenikih niso vključene oz. $\mathrm{v}$ zelo okrnjeni obliki $\mathrm{v}$ enem od njih. Večinoma so se avtorji odločili za glagole iz splošnega jezika, ki so sicer uporabni v vsakdanjem življenju, toda najpogostejših glagolov, ki bi jih bodoči študenti rabili pri svojem poklicu, ni. Predlagamo, da namesto glagola AVARE ali $L A V O R A R E$, avtorji uporabijo sintagmo PRENOTARE una camera, namesto TEMERE ali LEGGERE predlagamo PRENDERE una cappuccino, namesto SENTIRE ali DORMIRE, predlagamo OFFRIRE cene vegetariane, namesto FINIRE, predlagamo CAPIRE la lingua italiana. Ravno tako pri vajah z vstavljanjem ustreznih glagolskih oblik, namesto npr. Maria (restituire) il libro., predlagamo L'ospite (restituire) le chiavi della camera.

Tudi svojilni zaimki in pridevniki, s katerimi goste $\mathrm{v}$ nastanitvenih in gostinskih objektih večkrat nagovarjamo, so v analiziranih učbenikih obravnavani v lekciji s tematiko La famiglia e il lavoro (Družina in delo), ki je preveč splošne narave in za potrebe stroke precej nekoristna, zato namesto primerov kot je npr. "Questo è il gatto." predlagamo »Scusi, signora, mi dia la carta di identità!”.

\section{3}

\section{ZAKLJUČKI}

Učna gradiva so eden izmed temeljnih pripomočkov in gradnikov vsakega pouka tujih jezikov stroke, ki služijo predvsem temu, da ob njih študenti razvijajo strokovna in jezikovna znanja in dosegajo učne cilje (Mertelj, 2011b). V ospredju je na učenca in njegove poklicne potrebe osredinjen pristop. Izbiro učnih nalog, vaj in dejavnosti, ki jih vključimo v gradivo in učni proces, določa strokovno področje. V gradivo, ki je namenjeno bodočim zaposlenim v gostinstvu in turizmu, ki bodo s tujimi oziroma italijanskimi gosti v stiku predvsem govorno, je nujno integrirati čim več vsebinsko ustreznih besedil za jezikovni vnos, ki naj jih spremljajo naloge za razumevanje in tvorjenje strokovnega tujega jezika. Razvijajo naj komunikacijske kompetence, torej govorno razumevanje in 
sporazumevanje, kar pomeni čim več dejavnosti in učnih tehnik kot so igre vlog, simulirani dialogi v možnih gostinsko-turističnih situacijah in položajih.

Bistvena funkcija učnega gradiva za poučevanje in učenje tujega jezika gostinsko-turistične stroke je, da s pomočjo učnih vaj, nalog in dejavnosti spodbuja in razvija predvsem produktivno znanje učencev oziroma njihovo sposobnost, da neko misel ustno izrazijo. Raziskava je pokazala, da se učna gradiva, ki smo jih analizirali, večinoma opirajo na komunikacijski pristop in da torej večinoma spodbujajo učence, da se ustno izražajo, hkrati pa ugotovili tudi, da učne dejavnosti v gradivih poudarjajo razvoj govorne komunikacije predvsem gostov ali strank, ne pa tudi zaposlenih v gostinstvu in turizmu.

Delež nalog v analiziranih gradivih, ob katerih učenci urijo uporabo sporazumevalnih vzorcev in jezikovnih struktur za razvoj ustnega sporočanja, ki je osredinjen na položaj in vlogo zaposlenega v turizmu in gostinstvu, je vsekakor prenizek. Pomembno bi torej bilo, da bi avtorji učnih gradiv na tem področju namenili več pozornosti ustreznejšemu razmerju, torej tudi sporočanjskemu položaju zaposlenega v turistično-gostinski stroki (torej gostitelja) in ne primarno tistega, ki turistično-gostinske možnosti koristi (torej gosta).

V prispevku smo predlagali, da bi s pomočjo produktivnih nalog, ki temeljijo npr. na učnem prevajanju (iz materinščine v tuji jezik) najbolj pogostih in uporabnih povedi ali odgovorov in reakcij na vprašanja gostov, obiskovalcev in turistov v tipičnih turistično gostinskih situacijah, ter s pogosto uporabo iger vlog in simulacij učencu nudili pregled in urjenje uporabe bistvenih komunikacijskih vzorcev. Na ta način se bi preizkušal glede sposobnosti razumevanja prošenj svojih strank in se učil uporabljati strokovno značilne stavčne in sporazumevalne vzorce pri (postopoma vedno bolj) samostojnem tvorjenju ustne komunikacije.

$\mathrm{V}$ drugem delu raziskave smo ugotovili, da bi lahko v učbenike umestili več avtentičnega gradiva za urjenje receptivnih zmožnosti (bralnega razumevanja). Avtentična promocijska besedila nastanitvenih objektov so (lahko) izjemno dobre iztočnice za spoznavanje, razumevanje, urjenje in kasneje samostojno rabo ključnega strokovnega besedišča. Glede na to, da gre v našem primeru za slovenske študente gostinstva in turizma, se avtentična besedila, ki smo jih vključili med naše predloge in ki smo jih uporabili za receptivne dejavnosti, navezujejo na turistično ponudbo nastanitvenih obratov v Sloveniji (hotela, hostla, počitniške hiše) in v Italiji (hotela). S pomočjo pristnih besedil lahko učenci spoznavajo bogat besedni zaklad v strokovnem kontekstu. Med nalogami, ki naj bi preverjale in razvijale receptivno znanje učencev, torej njihovega razumevanje tujega jezika stroke, najdemo naloge, kjer učenci opazujejo, prepoznavajo in razvrščajo, izbirajo in povezujejo, pretvarjajo ali dopolnjujejo povedi, pa tudi prevajajo iz tujega jezika $\mathrm{v}$ materinščino (Mertelj, 2003; Stanič, 2013).

Uporabno učno gradivo za poučevanje tujega jezika stroke mora biti komunikacijsko zasnovano, slovnične strukture pa ne tiste, ki določajo zaporedje, zasnovo in/ali dinamiko učnih enot. Kljub temu naj bi tako gradivo omogočalo tudi urjenje slovničnih struktur, vendar samo tistih, ki so za doseganje strokovnega znanja jezika na določeni ravni potrebne in koristne. $\mathrm{V}$ naši raziskavi nas je delno zanimala količina ali prisotnost 
slovnice $\mathrm{v}$ učnih gradivih, delno pa tudi besedišče v vajah in nalogah za utrjevanje za stroko najpomembnejših slovničnih struktur. Slovnica in naloge za njeno urjenje v učbenikih, ki so namenjeni poučevanju določene stroke, naj bi bile preudarno in premišljeno zasnovane in umeščene $\mathrm{v}$ ustrezen strokovni kontekst.

Slovnične strukture je potrebno dosledno in smiselno povezati z njihovo uporabo v komunikaciji, slovnična pravilnost je pomembna do te mere, da pomaga pri razvijanju komunikacijske tekočnosti pri uporabi jezika, za to pa je vsebina slovničnih nalog bistvena. Ker smo ugotovili, da vsebujejo vaje v vseh treh učbenikih predvsem splošni jezik, smo predlagali, da se $\mathrm{v}$ urjenje slovnice integrirajo vsebine, ki so neposredni del realnih poklicnih izkušenj in situacij v gostinsko-turističnih dejavnostih.

\section{LITERATURA IN VIRI:}

BASTURKMEN, Helen (2010) Developing Courses in English for Specific Purposes. New Zealand: University of Auckland.

ČEPON, Slavica (2008) Učbeniki za poslovno angleščino - načini iskanja najboljšega. V: J. Skela (ur.), Učenje in poučevanje tujih jezikov na Slovenskem: pregled sodobne teorije in prakse. Ljubljana: Tangram.

DAGARIN-FOJKAR, Mateja (2008) Analiza učbenikov pri pouku angleškega jezika v drugem triletju osnovne šole. V: J. Skela (ur.), Učenje in poučevanje tujih jezikov na Slovenskem: pregled sodobne teorije in prakse. Ljubljana: Tangram.

DJURIĆ, Melita/Šarolta GODNIČ-VIČIČ/Violeta JURKOVIĆ (2008) Status učitelja tujega jezika stroke v slovenskem visokem šolstvu. M. Brkan, Š. Godnič Vičič, M. Jarc, V. Jurković in V. Zorko (ur.) Zbornik posveta ob 10. obletnici delovanja Slovenskega društva učiteljev tujega strokovnega jezika (Inter Alia 1). Ljubljana: SDUTSJ.

DJURIĆ, Melita/Šarolta GODNIČ-VIČIČ/Violeta JURKOVIĆ (2008) Tuji jeziki stroke v slovenskem visokem šolstvu: poimenovanje, ravni, obseg, cilji in učna gradiva. V: J. Skela (ur.), Učenje in poučevanje tujih jezikov na Slovenskem: pregled sodobne teorije in prakse. Ljubljana: Tangram.

DUDLEY-EVANS, Tony/Maggie Jo ST JOHN (1998) Developments in English for Specific Purposes. A multi-disciplinary approach. Cambridge: Cambridge University Press.

ELLIS, Rod (2003) Task-based language learning and teaching. Oxford: Oxfrod University Press.

GRANT, Neville (1987) Making the most of your textbook. Harlow: Longman.

HUTCHINSON, Tom/Alan WATERS (1987) English for Specific Purpose: A learning-centred approach. Cambridge: Cambridge University Press.

JARC, Mojca/Vida ZORKO (2013) Razvoj potrebe po učenju tujih strokovnih jezikov in vloga učitelja pri oblikovanju tujejezikovno kompetentnega diplomanta. Teorija in praksa, 50 (2). 
JORDAN, R. R. (1997) English for Academic Purposes. A guide and resource book for teachers. Cambridge: Cambridge University Press.

LAH, Meta (2010) Avtentična besedila pri pouku francoščine kot tujega jezika. Vestnik za tuje jezike, 2 (1-2). Ljubljana: Znanstvena založba Filozofske fakultete Univerze v Ljubljani.

MARIČIĆ, Maja (2011) Snovanje učbenika za italijanščino kot tuji jezik stroke na ravni A1 - koncept, vsebine, pristop (višješolski študijski program Gostinstvo in turizem). M. Brkan, S. Čepon, V. Jurković in D. Mertelj (ur.), Izzivi jezika strokev 21. stoletju: Zbornik konference Slovenskega društva učiteljev tujega jezika stroke (Inter Alia 2). Ljubljana: SDUTJS.

MERTELJ, Darja (2003) Naloge za urjenje slovničnih struktur v učbenikih italijanščine kot tujega jezika. Vestnik, 37 (1-2).

MERTELJ, Darja (2011a) Terminologia professionale in italiano / Strokovna terminologija v italijanskem jeziku. Gradivo za 1. in/ali 2. letnik višješolskega programa Gostinstvo in turizem. Š. Godnič-Vičič (ur.), Genres and Languages for Specific Purposes. Scripta Manent, 6, (1-2), Ljubljana: SDUTJS.

MERTELJ, Darja (2011b) Učni načrti, ravni znanja tujega jezika stroke in gradiva v višješolskih strokovnih programih. M. Brkan, S. Čepon, V. Jurković in D. Mertelj (ur.), Izzivi jezika stroke v 21.stoletju: Zbornik konference Slovenskega društva učiteljev tujega jezika stroke (Inter Alia 2). Ljubljana: SDUTJS.

NEWBY, David (2000) Authenticity. Fenner, A., D. Newby (ur.), 2000. Approaches to Materilas Design in European Textbooks: Implementing Principles of Authenticity, Learner Autonomy, Cultural Awareness. Strasbourg: Council of Europe.

PEČNIK, Gordana (2001) Srednješolska učbenika za poučevanje angleščine kot jezika stroke ter njuna evalvacija. Vestnik, 35 (1-2).

RIŽNAR, Igor (2008). Učna gradiva pri poslovni angleščini v slovenskem terciarnem izobraževanju. V: J. Skela (ur.), Učenje in poučevanje tujih jezikov na Slovenskem: pregled sodobne teorije in prakse. Ljubljana: Tangram.

RUIZ-GARRIDO, M. F./ J. C. PALMER-SILVEIRA/I. FORTANET-GÓMEZ (2010) Current trends in English for professional and academic purposes. M. F. Ruiz-Garrido, J. C. Palmer-Silveira, I. Fortanet-Gómez (ur.), English for professional and academic purposes (1-8). Amsterdam \& New York: Rodopi.

SKELA, Janez (1993) Evalvacija učbenikov tujega jezika. Vestnik, 27 (1-2).

SKELA, Janez (2008) Vrednotenje učbenikov angleškega jezika z vidika kognitivne teorije učenja. V: J. Skela (ur.), Učenje in poučevanje tujih jezikov na Slovenskem: pregled sodobne teorije in prakse. Ljubljana: Tangram.

SKUPNI EVROPSKI JEZIKOVNI OKVIR (2011): učenje, poučevanje, ocenjevanje. Ljubljana: Ministrstvo za šolstvo in šport. Dostopno na: http://www.mizs.gov.si/fileadmin/mizs.gov.si/pageuploads/SEJO_komplet_za_splet.pdf 
STANIČ, Daša (2012) Strokovna terminologija v italijanskem jeziku III - učbenika za višješolski študijski program Gostinstvo in turizem. Vestnik za tuje jezike, 4 (1-2). Znanstvena založba Filozofske fakultete Univerze v Ljubljani.

STANIČ, Daša (2013) Receptivno in produktivno znanje tujega in drugega jezika - analiza nalog na tekmovanju iz italijanščine 2013. Vestnik za tuje jezike, 5 (1-2). Znanstvena založba Filozofske fakultete Univerze v Ljubljani.

SVETLIN-GVARDJANČIČ, Polona (2008) Učitelj tujega jezika stroke. Metka Brkan, Š. Godnič Vičič, M. Jarc, V. Jurković in V. Zorko (ur.) Zbornik posveta ob 10.obletnici delovanja Slovenskega društva učiteljev tujega strokovnega jezika (Inter Alia 1). Ljubljana: SDUTSJ.

WEST, R. (1998). ESP - State of the Art. Dostopno na: http://www.man.ac.uk/CELSE/ esp/west.htm.

\section{POVZETEK}

$\mathrm{V}$ prispevku analiziramo jezikovne vsebine in tipologijo nalog oziroma dejavnosti za razvijanje učenčeve (ustne) komunikacijske spretnosti v razpoložljivih strokovnih učbeniških gradivih za gostinstvo in turizem, ki so nastali v slovenskem prostoru v zadnjih nekaj letih.

Sprašujemo se, v kolikšni meri in s pomočjo kakšnih nalog in dejavnosti lahko učenec razvija ustno sporazumevanje, predvsem pa, kakšna je njihova vsebina. Preučujemo tudi, kolikšna je prisotnost avtentičnega gradiva in nalog za urjenje produktivnih in receptivnih zmožnosti, ter $\mathrm{v}$ kolikšni meri je $\mathrm{v}$ gradivih strokovna terminologija integrirana $\mathrm{v}$ razlago s primeri in $\mathrm{v}$ utrjevanje najpomembnejših slovničnih struktur. Zanima nas torej, v kolikšni meri naloge v gradivih učenca usmerjajo in pripravljajo na samostojno komuniciranje v različnih poklicnih situacijah.

V raziskavi ugotavljamo, da so analizirana učna gradiva večinoma osnovana na komunikacijskem pristopu in da učence spodbujajo $\mathrm{k}$ ustnemu izražanju, hkrati pa ugotavljamo tudi, da je delež nalog, ob katerih učenci vadijo uporabo sporazumevalnih vzorcev in jezikovnih struktur $\mathrm{v}$ kontekstu zaposlenega v gostinsko turistični stroki, prenizek. Zato predlagamo, da se v učnih gradivih posveti več pozornosti sporočanjskim položajem zaposlenega $\mathrm{v}$ turistično-gostinski stroki in ne predvsem gostu oz. uporabniku turistično-gostinskih storitev. Ugotavljamo tudi, da bi se v učbenike moralo umestiti več avtentičnega gradiva, saj je najboljše izhodišče za spoznavanje, razumevanje in urjenje samostojne rabe ključne strokovne terminologije. Nenazadnje: tudi slovnične vaje vsebujejo predvsem splošni jezik, namesto da bi v urjenje slovnice vključili vsebine, ki so dejansko povezane z gostinsko in turistično stroko.

Ključne besede: italijanščina, tuji jezik stroke, gostinstvo in turizem, učna gradiva, govorno sporazumevanje, avtentična gradiva in naloge, tipologija nalog 


\section{ABSTRACT \\ Teaching Italian as a Foreign LSP in the Field of Tourism - Tasks Types in Textbooks and Some Proposals}

The article analyses the linguistic content and typology of exercises or activities designed to develop students' (verbal) communication skills in the available textbooks for Hospitality and Tourism published in Slovenia in the recent years.

The presented research aimed at establishing to what extent and with the help of what type of exercises and activities a student can develop oral communication and, in particular, to analyse the content of these exercises. The study is focused on the presence of authentic materials and tasks intended for practicing productive and receptive skills in the selected textbooks as well as on the extent to which the professional terminology is integrated in the interpretation together with the examples. Last but not least, focus is placed on the consolidation of the most important grammatical structures. Of special interest, therefore, is the extent to which the student is guided and prepared for independent communication in various professional situations with the help of textbook exercises.

The study revealed that the analysed learning material is mainly based on the communicative approach and that the students are encouraged to use oral expression. However, the share of exercises with which the students practice using the communicative patterns and language structures in the context of catering and tourism is too low. Our proposal is, therefore, that the teaching content should focus more on the communicative situations in which the professionals of tourism and hospitality find themselves, and should not primarily be oriented towards the guests or the users of tourism and hospitality services. In addition, the textbooks should contain more authentic material, since this is the best starting point for learning, understanding, and practising independent use of key professional terminology. Furthermore, even the grammatical exercises mostly include general language rather than the language and content that is intrinsically linked with catering and tourism.

Key words: Italian, foreign language for specific purposes, catering and tourism, study material, oral communication, authentic materials and exercises, task typology. 